\title{
A Description of Mathematical Communication Skills of Students Viewed from Hippocrates- Galeneuspersonality Type
}

\author{
Gunawan
}

\begin{abstract}
This research aims to know mathematical communication ability of students in class II C on integral calculus courses on the subject of integral applications viewed from Hippocrates-genius sanguine personality type which covers choleric, melancholy, and phlegmatic. The researchers used qualitative method to describestudents' skills on mathematical communication. The data collection was conducted by giving a personality type test which was represented by two samples of each personality type. The selected samples were given tests measuring mathematical communication skills and also were interviewed for the answers given. Results of the research shows that sanguine personality type meets all indicators of mathematical communication skills. Choleric personality type meet all indicators of mathematical communication skills. Melancholic personality type indicators meet two of mathematical communication skills by expressing or transferring daily life events into mathematical language or symbols and providing an explanation, idea, concept or mathematical situation using their own language in written form while student with a phlegmatic personality type meets two indicators of mathematical communication skills.
\end{abstract}

Keywords - Mathematical Communication Ability, HippocratesGaleneus Personality Type.

\section{INTRODUCTION}

Mathematical communication is an ability to convey an idea or notion either oraly or writen by using symbols, charts, or diagrams to explain a situation or problem from the information obtained. Mahmudi (2009) stated that mathematical communication covers written and oral communication. Written communication may present in the form of words, images, tables, which describe the thinking process of students. Written communication may present in a description of problem solving or mathematical proofing which

Mathematical communication ability is one of important capabilities and is expected to be mastered by students especially students in class II C of Mathematics Education Department, Faculty of Teacher Training and Education, Universitas Muhammadiyah Purwokerto. As stated and confirmed by Umar (2012), that learning should be able to help students in communicating mathematical ideas through four aspects of communication covering listening, reading,

Gunawan, Mathematics Education Department, Faculty of Teacher Training and Education, Universitas Muhammadiyah Purwokerto. writing and discussion. In addition, Umar (2012) stated that at least there are two important reasons why communication in learning math is important for students. First, math is not merely a means to think, discovering patterns, solving problems or taking the conclusions, math holds important role in communicating ideas clearly, precisely, and concisely. Second, mathematics as a social activity in learning, mathematics as an interactions media among students, as well as a communication means between teacher and student. Therefore, students need to be familiarized in learning to provide arguments against any answer and provide response toward the answers given by other people to give a meaning on studied material.

An analysis of students' mathematical communication skills was conducted during integral calculus coursein class II C of mathematics education department, Faculty of Teacher Training and Education, Universitas Muhammadiyah Purwokerto. Students of II C are in the transition from secondary level student education to the higher education. Students used to answering math problems directly without writing down the steps or process. Student did not get used to communicate or explain in detailto results.

Researchers conducted a review of mathematical communication ability of Hippocrates- Galeneus type covering sanguine, choleric, melancholic, and phlegmatic. Sanguine personality type has a very inspiring characterwhich is required to find a mathematical concept or idea. Melancholic personality type has dominant analytical, detailed Planner, idealistic, which is needed to the ability development in explaining mathematical steps consecutively. Analytical character owned by student allow them seeing the problem from different points of view from other people as well as the presence of high idealistic will trigger the presence of a new innovation. Choleric personality type has an independent character and also productive which lead in creating original products as a result of independency supported by productive character. Phlegmatic personality type which is easy to adapt is very possible to be flexible in responding disagreements.

The explanation above is a reason for researchers to conduct research on students' mathematical communication skills in class II C on integral application material observed from the the point of view of sanguine, melancholic, choleric, and phlegmatic personality types in mathematic education 
department, Faculty of Teacher Training and Education, Universitas Muhammadiyah Purwokerto on the course of integral calculus.

\section{RESEARCH METHODS}

\section{A. Type of Research}

This type of research is a descriptive qualitative, since the data collected are written material, words, or images. This study focuses on an overview of mathematical communication abilities of the student which furthermore the data obtained is presented in sentences.

\section{B. Research Procedure}

The research was conducted in three stages, namely preparation, data retrieval, and coverage. As for the elaboration of the respective answers are as follows:

\section{Preparation}

a) Defining a course which will be used as research namely calculus integral applications course.

b)Determining the class research, class II was considered as the sample.

c) Designing the instruments that will be used in research that is mathematical communication skills, personality type tests, and guidelines for the interview.

2. Data retrieval

a) The data of personality types which then are grouped into four personality types covering sanguine, melancholic, choleric, and phlegmatic.

b) Taking two samples of each type of personality to be tested on their ability of mathematical communication..

\section{RESULTS AND DISCUSSION}

The researcher gave the personality type test to students class II C on integral calculus courses, in mathematics education department, Faculty of Teacher Training and Education, Universitas MuhammadiyahPurwokerto.

Students' mathematical communication skills test consisted of two essay tests covering these indicators:

1. Reflecting images, tables, or charts into mathematical ideas.

2. Expressing the daily life event, concept, or mathematical symbols.

3. Providing an explanation of ideas, concepts or mathematical symbols using their own language in mathematical writing form.

The researcher tried to describe the test data of students' mathematical communication ability test in based on the answer of test number.

Question number 1. Calculate the area demarcated by the curve $y=x^{2}-2 x, y=-x^{2}$ and axisX.

Here are the explanation of the answer to question test about the ability of mathematical communication based on each personality type.

\section{A. Sanguine personality type}

a. Respondent $\mathrm{S}_{1}$

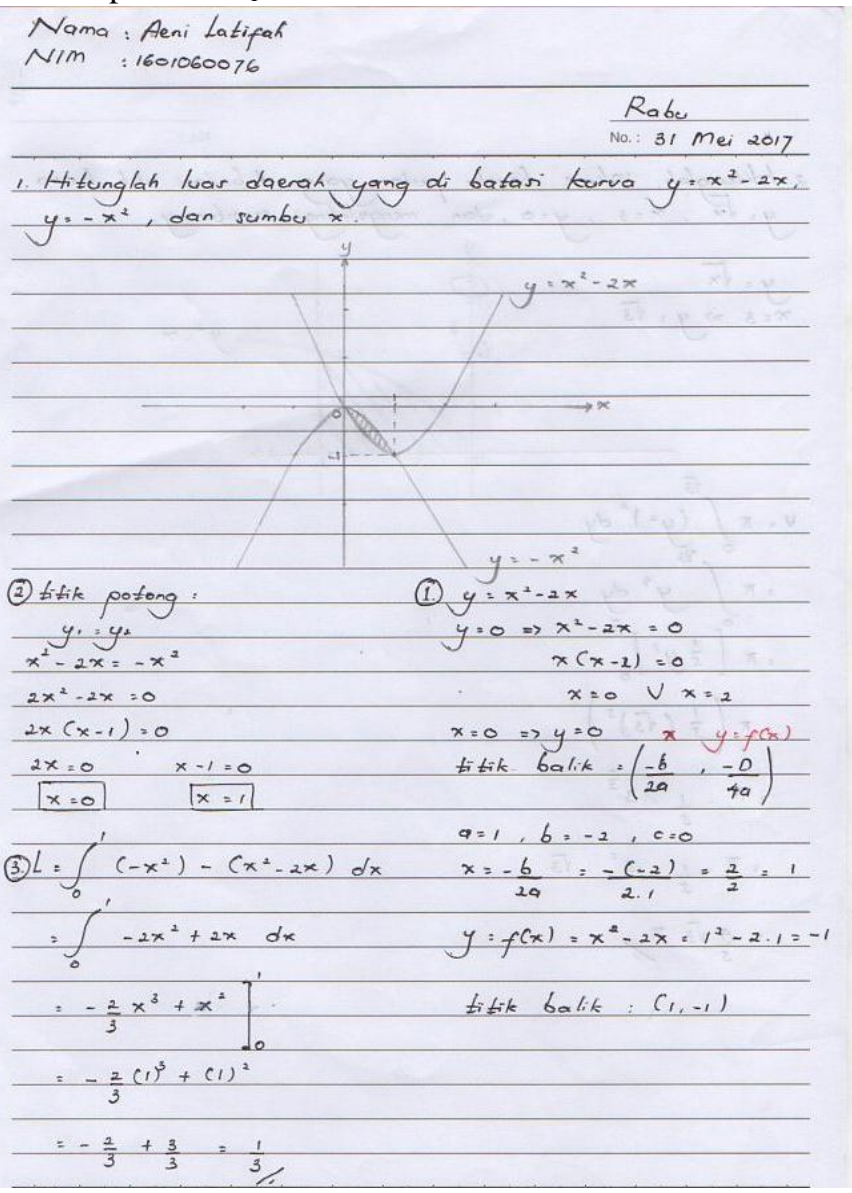

Fig. 4.2.The respondent's $S_{1}$ answer to question number 1

1) Reflecting images,tables, or charts into mathematical ideas.

$S_{1}$ Respondent answered by drawing an image of a curve which has been known. Answers given by respondent $S_{1}$ are correct because Respondent $S_{1}$ has already drawn shading to the intended area. In the interview, Respondent $S_{1}$ explained firmly and confidently, the image is also correct. The result shows that respondents $S_{1}$ are able to reflect the question in the form of a picture or graphic into mathematical ideas.

2) Expressing the daily life event in languages or mathematical symbols.

Picture 4.2 is the answer of respondents $S_{1}$. They answered question number 1 using mathematical language. It shows the students can solve the problem in question number 1 . In the interview, respondents $S_{1}$ are able to explain the way in solving the problem. This result indicates that Respondents $S_{1}$ are capable to declare the daily events into language or mathematical symbols.

3) Providing an explanation of ideas, concepts or mathematical symbols with their own language in the form of mathematics writing.

Respondent $S_{1}$ determined the limits point earlier which would be used with the similarities of the two curves. This indicates that students are able to draw the integrals 
boundary."

\section{B. Choleric Personality type}

Respondent $\mathrm{K}_{1}$

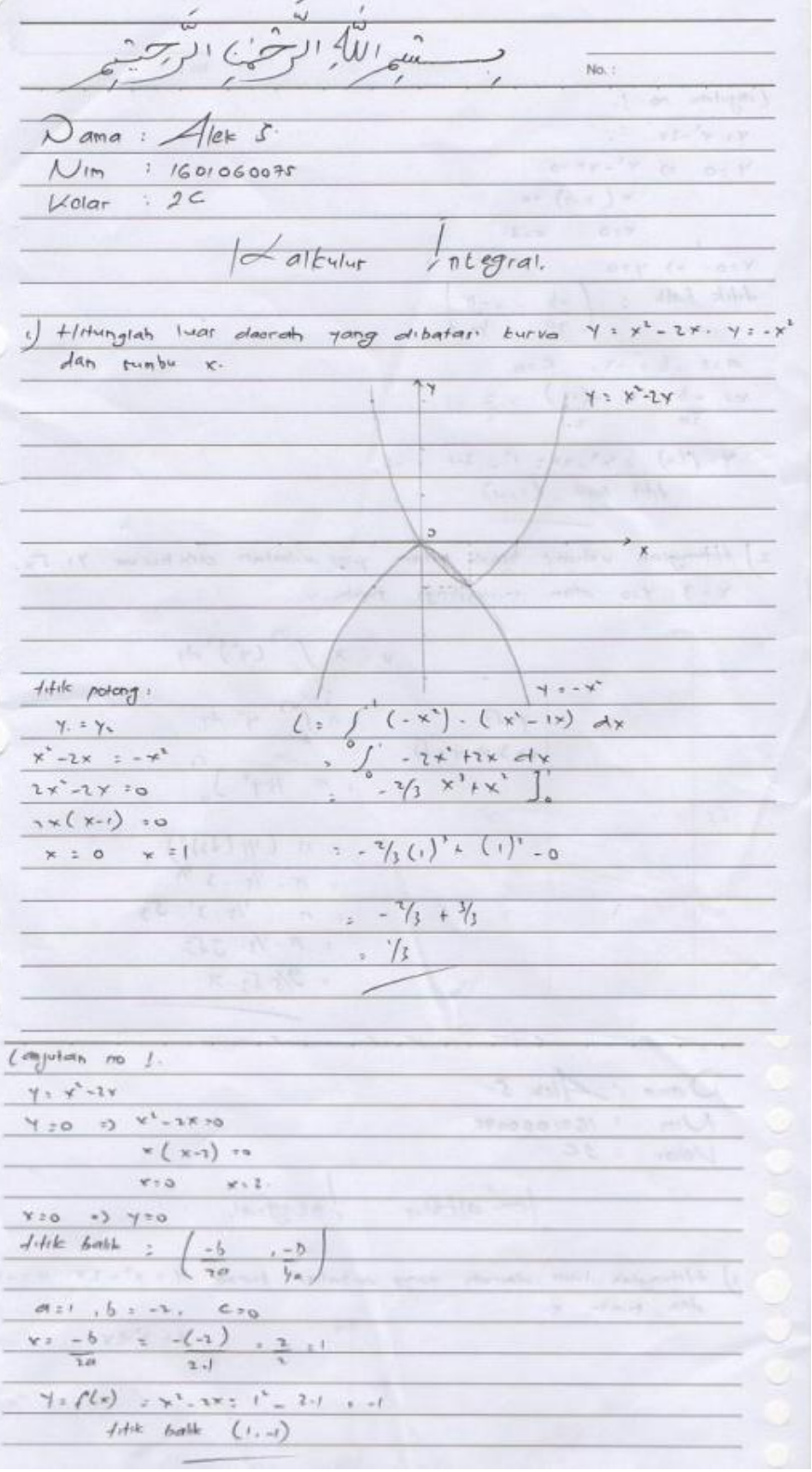

Fig. .4. The respondent's $\mathrm{K}_{1}$ answer to question number 1

1) Reflecting images, tables, or charts into mathematical ideas.

Picture 4.4shows the answers of Respondent 4 . Respondent 4 replied by describing known curve earlier. Then fill the intended area with shading. In the interview, respondent $K_{1}$ could explain how to draw, explaining the steps in the drawing. This shows the respondent $\mathrm{K}_{1}$ fully hasn't been able to link the pictures, tables, and, charts into mathematical ideas.

2) Expressing the daily event using languages or mathematical symbols.

Picture 4.4 shows the results of an answer from the respondent $\mathrm{K}_{1}$. The Respondent did not use any symbol in answering the question. In the interview, respondent $\mathrm{K}_{1}$ said that he forgot and felt confused in answering the question. This indicates that respondents $\mathrm{K}_{1}$ hasn't been able to express daily events into language or mathematical symbols.

3) Providing an explanation of ideas, concepts or mathematical symbols with their own language in mathematical writing form.

The third respondents or respondents $\mathrm{K}_{1}$ did not answer the integral value.

\section{Melancolic personality type}

\section{Respondent $\mathrm{M}_{1}$}

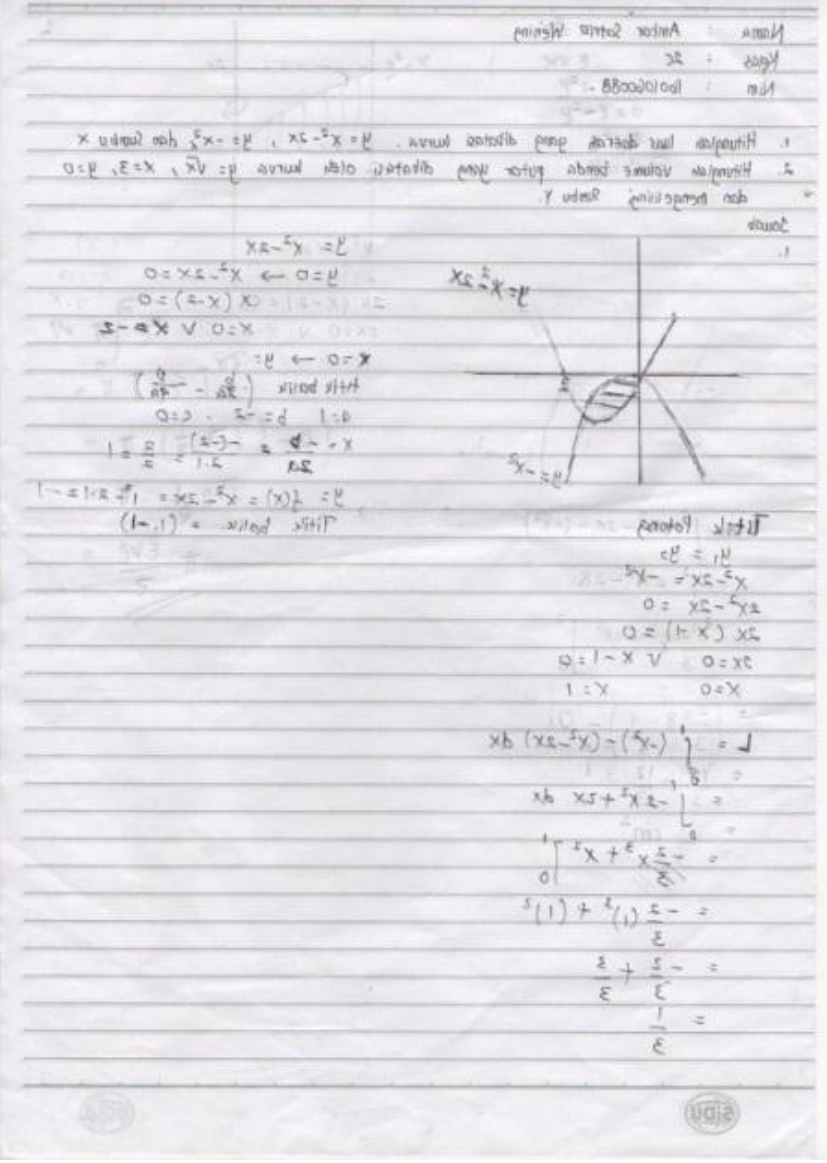

Fig.5 an answer of respondent $\mathrm{M}_{1}$ to question number 1

1) Reflecting picture,tables, or charts into mathematical ideas.

Picture 4.5 explains the picture from the respondent $M_{1}$. respondents $\mathrm{M}_{1}$ answered correctly and appropriately. Respondent $\mathrm{M}_{1}$ determined the intersection of the curves, then determines the peak point of the curve, and determining the limit of the curve with the equality concept of two curves. This proves the respondent $\mathrm{M}_{1}$ has already understood the question and can answer it. In the interview, respondent $\mathbf{M}_{1}$ could explain the intersection point, peak point, and limit point of the curves. This showed Respondent $\mathrm{M}_{1}$ was able in connecting images, tables, and graphs into mathematical ideas.

2) Expressing the daily event in languages or mathematical symbols.

As shown on picture 4.5 , the respondent $\mathrm{M}_{1}$ answered 
correctly question number 1 . It can be seen from the symbols used such as the width of disjunction area. This shows that students can solve the problem in question number 1 . In the interviews, respondent $\mathrm{M}_{1}$ said that students may explain the symbols used. This indicates that respondent M1 is able to express the daily events into language or mathematical symbols.

3) Providing an explanation of ideas, concepts or mathematical symbols using their own language in the form of mathematical writing.

The third respondent is Respondent $\mathrm{M}_{1}$. Respondent $\mathrm{M}_{1}$ answered the rule in using finite integral appropriately and correctly.

\section{D.Phlegmatic Personality type}

a. Respondent $\mathrm{P}_{1}$

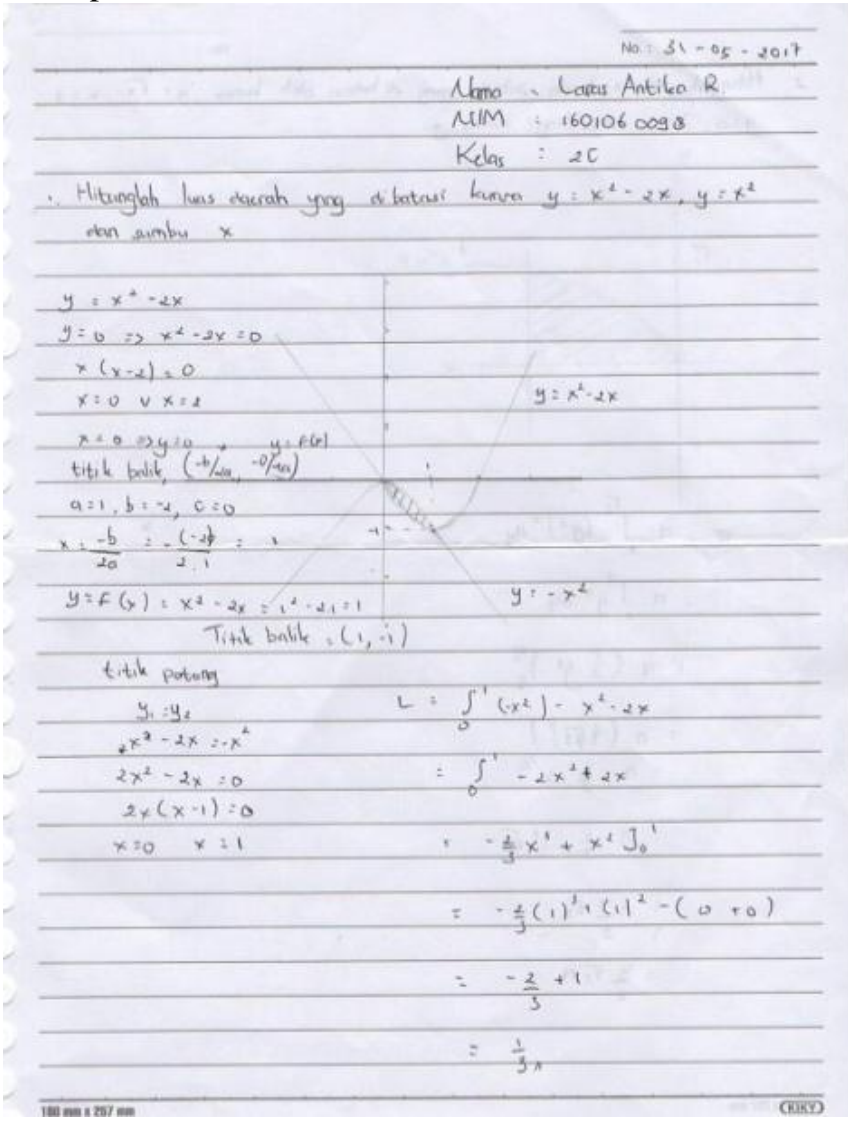

Fig. 4.6. The answer of respondent's $\mathrm{P}_{1}$ to question number 1

1) Reflecting image, tables, or charts into mathematical ideas.

As shown on Picture 4.6, Respondent $\mathrm{P}_{1}$ answered correctly.They drew intended area earlier before answering the questions to facilitate in answering the question. Students also determined peak point and the intersection point first. The objective is to know the boundaries of the two curves. Respondents $\mathrm{P}_{1}$ has already understood how to draw a curve. In the interview, Respondent $\mathrm{P}_{1}$ can explain how to draw a quadratic function, define the limit point, and the rule of finite integral. This shows the Respondent $\mathrm{P}_{1}$ is able to fully link the image, tables, graphs into mathematical ideas.

2) Expressing daily event in languages or mathematical symbols.

As shown from the picture above, the respondent $\mathrm{P}_{1}$ answered correctly the question. This indicates that Respondent $P_{1}$ understand the problem in question number 1. During the interview, the respondent $P_{1}$ explained that he has already known and understand how to define integrals, this shows that Respondents $\mathrm{P}_{1}$ has already been able to express the daily event in languages or mathematical symbols.

3) Providing an explanation of ideas, concepts or mathematical symbols with their own language the form of mathematics writing.

As shown on picture 4.6. In answering question, Respondent $\mathrm{P}_{1}$ draw the the curve, the drawing is clearly visible shows the interval boundary which will be used to calculate integrals. Respondents $\mathrm{P}_{1}$ also drew the second diagram of both curve correctly. When the respondent was interviewed, respondent $\mathrm{P}_{1}$ can explain how to calculate the turning point by using the formula $\left(\frac{-b}{2 a}, f\left(\frac{-b}{2 a}\right)\right)$. In addition, it can also explain how to calculate the amount using the integral formulas $\int_{a}^{b} f(x) d x=F(b)-F(a)$ with $\mathrm{F}$ (x) is the derivative of $\mathrm{f}(\mathrm{x})$. Respondents $\mathrm{P}_{1}$ felt confident with his answers. This indicates that Respondents $\mathrm{P}_{1}$ is able to provide an explanation, idea, concept or mathematical situation using his own language in written and oral form.

\section{CONCLUSION}

Based on the results description and discussion, it can be concluded that the students' communication ability of math class II C on calculus integral courses with the main discussin of integral application as follows:

1. Respondents with communication capability on Sanguine personality types are capable in fulfilling the three indicators of students'mathematical communication ability.

2. Respondents with communication skills on the type Choleric personality can understand the problem well. Therefore, respondents with communication capability on Choleric personality type meet all indicators ofmathematical communication skills.

3. Respondents with communication skills on a Melancholy personality type can understand the problem well. As for problem number 1 meet all indicators of mathematical communication skills.

4. Respondent meet all indicators of mathematical communication ability at both given question.

\section{REFERENCES}

[1] Bistari. (2010). Pengembanagan Kemandirian Belajar Berbasis Nilai untukMeningkatkan Komunikasi Matematika. Jurnal Pendidikan Matematikadan IPA, 1(1), $11-23$. 
[2] Littauer, F. (2015). Your Personality Tree. Surabaya: MIC (Menuju Insan Cemerlang).

[3] Gafari, O. (2008). Komunikasi Dalam Manajemen Pendidikan. EduSentris, 2(2), 45- 67. Diakses dari :http://jurnal.upi.edu.

[4] Khalid, M. dan Tengah, M.K.A. (2008). Communication in Mathematics: The Role of Language and Its Consequences for English as Second Language Students. Diakses dari http://www.criced.tsukuba.ac.jp/math/apec/apec2008/papers/PDF/7.Ma dihah_Khalid_Brunei.pdf.

[5] Mahmudi, A. (2009). Komunikasi dalam Pembelajaran Matematika. Yogyakarta. Jurnal MIPMIPA UNHALU, 8(1), 1-9. Diakses dari: :http://staff.uny.ac.id/sites/default/files/penelitian/Ali\%20Mahmudi,\%2 0S.Pd,\%20M.Pd,\%20Dr./Makalah\%2006\%20Jurnal\%20UNHALU\%20 2008\%20_Komunikasi\%20dlm\%20Pembelajaran\%20Matematika_.pdf

[6] Umar, W. (2012). Membangun Kemampuan Komunikasi Matematis dalam Pembelajaran Matematika. Jurnal Ilmiah rogram Studi Pendidikan Matematika STKIP Siliwangi Bandung, 1(1), 1-9. Diakses dari: $\quad$ http://publikasi.stkipsiliwangi.ac.id/files/2012/08/WahidUmar.pdf.

[7] Utari, S. (2005). Meningkatkan Komunikasi Matematik Siswa Smp Melalui Realistic Mathematics Education (Rme) Dalam Rangka Menuju Sekolah Bertaraf Internasional (Sbi). EduSentris, 1(2), 1-9. Diakses dari :http://jurnal.upi.edu. [2 Maret 2017]

[8] Yusuf, S., \& Nurihsan, J. (2011). TeoriKepribadian. Bandung: RemajaRosdakarya. 